\title{
Serum cortisol concentration in cattle of different genetic groups slaughtered in confinement
}

\section{Concentração de cortisol sérico em bovinos de diferentes grupos genéticos terminados em confinamento}

\author{
Aracele Pinheiro Pales ${ }^{1 *}$; João Teodoro Padua ${ }^{2}$; Klayto José Gonçalves dos Santos ${ }^{1}$; \\ Karyne Oliveira Coelho' ${ }^{1}$; Claudia Peixoto Bueno ${ }^{3}$; Rafael Alves da Costa Ferro ${ }^{1}$; \\ Diogo Alves da Costa Ferro ${ }^{3}$; Raiany Soares de Paula ${ }^{4}$
}

\begin{abstract}
The objective of this work was to compare the serum cortisol levels among four genetic cattle groups slaughtered in confinement. Thirty-two non-castrated male bovines from four genetic groups were analyzed: Nelore, Aberdeen Angus $\times$ Nelore, Caracu $\times$ Nelore, and Guzerá $\times$ Nelore. The blood samples were collected on the day of weighing (every 28 days) and during the slaughter. Regarding the concentration of serum cortisol, no significant differences were found among the groups during the first, second, and fourth collections. However, during the third collection and at the day of slaughter, respectively, the Nelore group $(3.15 \mathrm{ng} / \mathrm{dL} ; 2.98 \mathrm{ng} / \mathrm{dL})$ showed similarity to the Caracu $\times$ Nelore $(2.02$ $\mathrm{ng} / \mathrm{dL} ; 2.07 \mathrm{ng} / \mathrm{dL})$ and Guzerá $\times$ Nelore $(2.33 \mathrm{ng} / \mathrm{dL} ; 2.40 \mathrm{ng} / \mathrm{dL})$ groups. Nelore showed a significant difference compared with the Aberdeen Angus $\times$ Nelore group $(1.21 \mathrm{ng} / \mathrm{dL} ; 1.61 \mathrm{ng} / \mathrm{dL})$. With respect to the overall collection averages, the Nelore group $(2.85 \pm 0.87 \mathrm{ng} / \mathrm{dL})$ showed greater values than the Aberdeen Angus $\times$ Nelore group $(1.61 \pm 0.87 \mathrm{ng} / \mathrm{dL})$. However, it showed similarities to the Caracu $\times$ Nelore $(2.06 \pm 1.31 \mathrm{ng} / \mathrm{dL})$ and Guzerá $\times$ Nelore $(2.48 \pm 1.16 \mathrm{ng} / \mathrm{dL})$ groups. It was also observed that animals with low cortisol values gained more weight, as demonstrated by the correlation between ADG and the cortisol collection averages $(-0.54 ; \mathrm{p}<0.05)$. There was no difference among the groups with respect to shearing strength of the meat, and the correlation between this force and the cortisol collection average $(0.15 ; \mathrm{p}>0.05, \mathrm{~ns})$ showed that meat tenderness in the studied groups was not affected.
\end{abstract}

Key words: Shearing strength. Meat tenderness. Beef steers.

\section{Resumo}

Objetivou-se através deste trabalho comparar o nível sérico de cortisol em quatro grupos genéticos de bovinos terminados em confinamento. Foram avaliados 32 bovinos machos não castrados de quatro grupos genéticos, sendo estes: Nelore, Aberdeen Angus x Nelore, Caracu x Nelore e Guzerá x Nelore. As amostras de sangue foram coletadas nos dias das pesagens, a cada 28 dias e durante o abate, na sangria, para posterior dosagem do cortisol plasmático. Para a concentração de cortisol sérico, não foram encontradas diferenças significativas entre os grupos, na primeira, segunda e quarta coleta, porém na terceira coleta e na coleta do dia do abate, respectivamente o grupo Nelore $(3,15 \eta \mathrm{g} / \mathrm{dL} ; 2,98 \eta \mathrm{g} /$

${ }^{1}$ Profs., Universidade Estadual de Goiás, UEG, Campus São Luís de Montes Belos, GO, Brasil. Bolsista PROBIP/UEG. E-mail: aracele.pales@ueg.br; klayto.santos@ueg.br; kocoelho@hotmail.com; rafael.ferro@ueg.br

2 Prof., UFG, Goiânia, GO, Brasil. E-mail: teodoro@ufg.br

3 Profs., UEG, Campus São Luís de Montes Belos, GO, Brasil. E-mail: claudia.bueno@ueg.br; diogo.ferro@ueg.br

${ }^{4}$ Discente de Mestrado em Desenvolvimento Rural Sustentável, UEG, Campus São Luís de Montes Belos, GO, Brasil. E-mail: raiany_soares@hotmail.com

* Author for correspondence 
dL), foi semelhante ao grupo Caracu x Nelore $(2,02 \eta \mathrm{g} / \mathrm{dL} ; 2,07 \eta \mathrm{g} / \mathrm{dL})$ e ao grupo Guzerá x Nelore $(2,33 \eta \mathrm{g} / \mathrm{dL} ; 2,40 \eta \mathrm{g} / \mathrm{dL})$ se diferindo significativamente do grupo Aberdeen Angus x Nelore $(1,21 \eta \mathrm{g} /$ $\mathrm{dL} ; 1,61 \eta \mathrm{g} / \mathrm{dL})$. Avaliando a média geral das coletas, o grupo Nelore $(2,85 \eta \mathrm{g} / \mathrm{dL} \pm 0,87)$ é superior ao grupo Aberdeen Angus x Nelore $(1,61 \eta \mathrm{g} / \mathrm{dL} \pm 0,87)$, porém se assemelhando aos grupos e Caracu x Nelore $(2,06 \eta \mathrm{g} / \mathrm{dL} \pm 1,31)$ e Guzerá $\mathrm{x}$ Nelore $(2,48 \eta \mathrm{g} / \mathrm{dL} \pm 1,16)$. Foi constatado ainda que animais que apresentaram valores baixos de cortisol, ganharam mais peso demonstrado pela correlação entre GMD e a média das coletas de cortisol $(-0,54 \mathrm{e} \mathrm{p}<0,05)$. Para força de cisalhamento não houve diferença entre os grupos, demonstrando ainda correlação entre força de cisalhamento e média de coleta de cortisol $(0,15$ e $\mathrm{p}>0,05 \mathrm{~ns})$ que não interferiu na maciez da carne destes grupos estudados.

Palavras-chave: Força de cisalhamento. Maciez da carne. Novilhos de corte.

\section{Introduction}

The bovine meat supply chain continues to gain prominence worldwide because of increased demand in the international market and the low costs of Brazilian bovine meat production, thus, making this market highly competitive. The high level of competition today, owing to an increasingly demanding market, makes efficiency a basic requirement for the survival of any sector, and progressively new techniques are adopted by producers to meet goals and increase profitability.

Confinement has been a highly utilized option during the final stage of the cattle raising process, despite the large-scale livestock pasture farming for meat prevalent in Brazil. When livestock are exposed to repeated environmental changes such as confinement, their level of well-being is altered, as they face a situation different from what they are adapted to, forcing them to readapt.

Physiological indicators, such as plasma cortisol levels, can be used to quantify temperament. Such physiological measures of response to stress have been widely used to evaluate the well-being of animals in agricultural procedures, therefore, making it necessary for researchers to better understand bovine reactivity, and quantifying it according to the various methods of livestock farming and handling (SILVA et al., 2014).

Cortisol facilitates glycogenesis and lipid metabolism, protects the vascular tree response, modulates central nervous system functioning, and negatively affects the immune response (KANITZ et al., 2009). As a result, cortisol is considered an important glucocorticoid that relates directly to biomolecular metabolism, as it circulates in the blood while being linked to an alpha globulin (ALVARENGA et al., 2015).

Methods for handling and appropriate selection of animals should be studied in order to minimize complications and their negative consequences, since aggressive behavior and the consequent cortisol increase are associated with carcass of inferior quality (SILVA et al., 2014). Kabuga and Appiah (1992) suggested that the ease of cattle handling is influenced a lot more by the raising conditions and experience of the farmer than it is by genetics, after studying Bos indicus that were crossbred with Bos taurus steers. The researchers did not find any differences in temperament between the genetic groups.

The objective of this work was to determine cortisol quantities in different genetic groups, and to find whether these correlate with carcass and meat characteristics, considering that temperament can influence animal productivity.

\section{Materials and Methods}

The experiment was conducted at a large rural property in the city of São Luís de Montes Belos, GO (Goiás state), located at $125 \mathrm{~km}$ along interstate GO 060. The average annual temperature varies from 18.3 to $31.7^{\circ} \mathrm{C}$, with an average annual relative humidity of $73 \%$, and $1650.9 \mathrm{~mm}$ precipitation. 
The animals were distributed among confinement boxes immediately after weaning, resulting in an equal average weight for each box. To ensure reproducibility of the results, each box housed four animals of the same genetic group, and there were a total of eight such boxes. After a period of 56 days for adaptation, during which the animals received food freely, identification and marking through ear tags and initial weighing was conducted.

Thirty-two non-castrated male bovines from four genetic groups were evaluated: Nelore, Aberdeen Angus $\times$ Nelore, Caracu $\times$ Nelore, and Guzerá $\times$ Nelore. For each genetic group, eight bovines of similar age were used. These animals were clinically healthy and seven months old ( \pm 2 months), with an average weight of $180 \mathrm{~kg}( \pm 20 \mathrm{~kg})$, and had grazed extensively before the experiment. The animals were fed ad libitum with a diet composed of $73.90 \%$ corn silage and $26.09 \%$ concentrate based on dry matter, containing $23 \%$ raw protein.

The animals were weighed every 28 days, after a fasting period of $16 \mathrm{~h}$ without water and food, following the standard weighing protocols. During the weighing, arterial tail blood was collected for subsequent cortisol analysis. Average temperatures and wind speeds were also recorded during the collection days $\left(1^{\text {st }}\right.$ collection: $27.5^{\circ} \mathrm{C}$ and $3.5 \mathrm{~m} / \mathrm{s}$; $2^{\text {nd }}$ collection: $26^{\circ} \mathrm{C}$ and $4.5 \mathrm{~m} / \mathrm{s}, 3^{\text {rd }}$ collection: $28^{\circ} \mathrm{C}$ and $3.3 \mathrm{~m} / \mathrm{s}, 4^{\text {th }}$ collection: $26.5^{\circ} \mathrm{C}$ and $4.2 \mathrm{~m} / \mathrm{s} ; 5^{\text {th }}$ collection: $27^{\circ} \mathrm{C}$ and $4.0 \mathrm{~m} / \mathrm{s}$ ).

Vacuum blood tubes were used for obtaining 10 $\mathrm{ml}$ blood samples without using anticoagulant, for cortisol extraction. The samples were centrifuged (2,500 rpm for $10 \mathrm{~min}$ ), and the serum was divided into aliquots that were immediately frozen for later processing in a clinical laboratory (TIETZ, 1995).

When the feedlots reached an average weight of $450 \mathrm{~kg}$, the animals were subjected to fasting from food for $16 \mathrm{~h}$, followed by weighing and transportation to the meat packing facility, and slaughtered after $18 \mathrm{~h}$ of rest with a water diet. Animals were slaughtered in a commercial meat packing facility, and stunned with a captive bolt pistol following the facility's standard procedures. Blood samples were collected for plasma-cortisol determination during bloodletting in the slaughter line. After serum separation, the samples were frozen and later sent for analysis.

Following this stage, a section denominated "HH" was removed from between the $10^{\text {th }}$ and $12^{\text {th }}$ ribs, following the methodology proposed by Hankins and Howe (1946) and adapted by Muller (1987). Analysis of the shearing force was conducted after boiling and weighing a $2.5-\mathrm{cm}$ long piece of steak taken from the $\mathrm{HH}$ section, from where eight cylinders of $1-\mathrm{cm}$ diameter each were extracted parallel to the fibers, using a hollow punch coupled to a drill in an iron support modified for this purpose. Immediately afterwards, these cylinders were cut perpendicularly to the fibers with a Warner Bratzler Meat Shear, which measures the resistance of the fibers against cutting, based on the shearing strength. The average values obtained from the cylindrical samples of each evaluated steak were considered as the final shearing force values.

The experiment was carried out with four treatments applied on eight animals in each group. Each group was divided into two subgroups, containing four animals each. During the statistical analyses, Tukey's test was conducted using the computational program SAS (2000), in addition to computing the Pearson correlation coefficient, for comparing treatment averages across variables.

\section{Results and Discussion}

The recorded cortisol levels did not statistically differ among the treatments in the first, second, and fourth collections made, as shown in Table 1. However, in the third and the last collection, during slaughter, the Nelore group showed levels similar to the groups Guzerá $\times$ Nelore and Caracu $\times$ Nelore, and greater than the group Aberdeen Angus $\times$ Nelore. 
From the evaluation of serum cortisol levels at the moment of slaughter, a significant difference can be seen between the groups Nelore $(2.98 \mathrm{ng} / \mathrm{dL})$ and Aberdeen Angus $\times$ Nelore $(1.61 \mathrm{ng} / \mathrm{dL})$, with higher cortisol levels for the Bos taurus indicus animals.
According to Ottersbach et al. (2008), who analyzed the cortisol variability in two bovine groups (Bos taurus indicus and Bos taurus indicus $\times$ Bos taurus taurus) at the slaughter line, serum cortisol levels are a useful way to evaluate bovine stress levels.

Table 1. Averages and standard deviation of the cortisol serum concentrations at different collection points and during slaughter, for four bovine genetic groups in confinement: Nelore (N), Aberdeen Angus $\times$ Nelore (AN), Caracu $\times$ Nelore $(\mathrm{CN})$, and Guzerá $\times$ Nelore $(\mathrm{GN})$.

\begin{tabular}{cccccc}
\hline \multirow{2}{*}{ ng/dL } & \multicolumn{5}{c}{ Genetic Groups } \\
\cline { 2 - 6 } & $\mathbf{N}$ & $\mathbf{A N}$ & $\mathbf{C N}$ & $\mathbf{G N}$ & $\mathbf{C V}$ \\
\hline Collection 1 & $2.38 \pm 1.03^{\mathrm{a}}$ & $2.00 \pm 1.13^{\mathrm{a}}$ & $2.08 \pm 1.21^{\mathrm{a}}$ & $2.23 \pm 1.34^{\mathrm{a}}$ & 54.51 \\
Collection 2 & $2.97 \pm 1.20^{\mathrm{a}}$ & $1.73 \pm 1.03^{\mathrm{a}}$ & $2.13 \pm 2.00^{\mathrm{a}}$ & $3.06 \pm 1.09^{\mathrm{a}}$ & 57.36 \\
Collection 3 & $3.15 \pm 0.87^{\mathrm{a}}$ & $1.21 \pm 0.72^{\mathrm{b}}$ & $2.02 \pm 1.10^{\mathrm{ab}}$ & $2.33 \pm 1.50^{\mathrm{ab}}$ & 51.49 \\
Collection 4 & $2.81 \pm 0.64^{\mathrm{a}}$ & $1.52 \pm 0.72^{\mathrm{a}}$ & $2.01 \pm 1.19^{\mathrm{a}}$ & $2.41 \pm 1.02^{\mathrm{a}}$ & 42.92 \\
Collection 5 & $2.98 \pm 0.65^{\mathrm{a}}$ & $1.61 \pm 0.78^{\mathrm{b}}$ & $2.07 \pm 1.09^{\mathrm{ab}}$ & $2.40 \pm 0.87^{\mathrm{ab}}$ & 39.79 \\
\hline "slaughter" & & & & 35.08 \\
\hline Overall Average & $2.85 \pm 0.87^{\mathrm{a}}$ & $1.61 \pm 0.87^{\mathrm{b}}$ & $2.06 \pm 1.31^{\mathrm{ab}}$ & $2.48 \pm 1.16^{\mathrm{ab}}$ & 35 \\
\hline
\end{tabular}

Averages followed by the same letters in the same row/column do not show significant differences ( $\mathrm{p}>0.05$; Tukey's test).

Considering cortisol as a physiological indicator of bovine stress, it is suggested that the Aberdeen Angus $\times$ Nelore group $(1.61 \pm 0.87 \mathrm{ng} / \mathrm{dL})$ has the closest cortisol levels to the average value from the collections, which is lower in comparison to the Nelore group and similar to the other groups. This means that the Aberdeen Angus $\times$ Nelore group is less susceptible to stress, demonstrating the influence of European blood on the Nelore breed.

From the values for climactic conditions on the third cortisol-collection day, one can observe a higher average temperature $\left(28^{\circ} \mathrm{C}\right)$ and a lower wind speed $(3.3 \mathrm{~m} / \mathrm{s})$ in comparison to the other days. On the day of slaughter, high levels of solar radiation were also noted, which might have caused thermal discomfort in the animals. With respect to hormone levels, it is known that stress conditions can cause significant effects on the physiology of animals. Various forms of stress, including thermal stress, cause an increased secretion of adrenocorticotropic hormone (ACTH), leading to a greater release of glucocorticoids through the adrenal cortex. These molecules are responsible for regulating the intensity of the stress response, with cortisol being the primary hormone responsible for restoring homeostasis. Cortisol is released after an animal's exposure to stressful situations (POCAY et al., 2001; FRASER; RUSHEN, 1987; RANDALL, 2011). This fact relates to the results observed in the present experiment.

The average values for daily gain, slaughter weight, hot carcass weight, carcass profitability, and shearing force for different genetic groups are listed in Table 2.

The Aberdeen Angus $\times$ Nelore group shows a greater average daily gain (ADG), slaughter weight (SLW), and hot carcass weight (HCW) in comparison to the others. However, the $\mathrm{CP}$ of the Aberdeen Angus $\times$ Nelore group is similar to the Nelore group. In general, crosses between European breeds and zebu animals result in descendants with greater ADG and SLW, a fact that was also noted by Abrahão et al. (2005), in concordance with the observations in this experiment for the Aberdeen Angus $\times$ Nelore group. 
Table 2. Average daily gain (ADG), slaughter weight (SLW), hot carcass weight (HCW), carcass profitability (CP), and shearing force (SF) for four bovine genetic groups slaughtered in confinement: Nelore $(\mathrm{N})$, Aberdeen Angus $\times$ Nelore (AN), Caracu $\times$ Nelore $(\mathrm{CN})$, and Guzerá $\times$ Nelore $(\mathrm{GN})$.

\begin{tabular}{cccccc}
\hline Parameters & \multicolumn{5}{c}{ Genetic Groups } \\
\cline { 2 - 6 } Evaluated & $\mathbf{N}$ & $\mathbf{A N}$ & $\mathbf{C N}$ & $\mathbf{G N}$ & $\mathbf{C V} \%$ \\
\hline ADG, $\mathrm{kg}$ & $0.65 \pm 0.14^{\mathrm{c}}$ & $1.28 \pm 0.15^{\mathrm{a}}$ & $0.98 \pm 0.13^{\mathrm{b}}$ & $0.85 \pm 20.23^{\mathrm{bc}}$ & 15.53 \\
$\mathbf{S L W}, \mathrm{kg}$ & $433.37 \pm 39.20^{\mathrm{c}}$ & $627.50 \pm 50.61^{\mathrm{a}}$ & $505.75 \pm 39.20^{\mathrm{b}}$ & $476.62 \pm 41.60^{\mathrm{bc}}$ & 8.40 \\
$\mathbf{H C W}, \mathrm{kg}$ & $227.62 \pm 23.63^{\mathrm{b}}$ & $335.87 \pm 31.48^{\mathrm{a}}$ & $258.62 \pm 19.41^{\mathrm{b}}$ & $245.00 \pm 27.86^{\mathrm{b}}$ & 9.66 \\
$\mathbf{C P}, \%$ & $52.50 \pm 1.06^{\mathrm{ab}}$ & $53.50 \pm 1.30^{\mathrm{a}}$ & $51.12 \pm 1.24^{\mathrm{b}}$ & $51.37 \pm 1.50^{\mathrm{b}}$ & 2.45 \\
SF kgf $^{\mathrm{c}} \mathrm{cm}^{2}$ & $6.42 \pm 1.29^{\mathrm{a}}$ & $5.41 \pm 0.55^{\mathrm{a}}$ & $5.88 \pm 1.55^{\mathrm{a}}$ & $6.13 \pm 2.02^{\mathrm{a}}$ & 22.39 \\
\hline
\end{tabular}

Averages followed by the same letters in the same row/column do not show significant differences $(p>0.05)$.

According to Brown et al. (2004), genetic factors can contribute to behavioral differences observed in cattle used for slaughter, with animals of calmer temperaments showing greater weight gain. The results obtained in this experiment support this, not through the evaluation of temperament, but through the lesser susceptibility to stress observed in the Aberdeen Angus $\times$ Nelore group compared with the Nelore group. According to Silveira et al. (2006), crossbred animals with zebu predominance show a greater reactivity in comparison to those with European predominance.

Temperament can be defined as a set of animal behaviors, commonly attributed to fear, similar to human behavior. Animals that were more anxious gained 10-14\% less weight on a daily basis, compared with the calmer animals (VOISINET et al., 1997).

Tablet 2 shows that animals from the Aberdeen Angus $\times$ Nelore group had a greater weight gain compared to others, supporting Barbosa et al. (2008), who evaluated Charolais and Nelore steers in confinement, reporting that animals with greater percentage of zebu blood showed more excitable temperament, in addition to less weight gain. However, regardless of the genotype, bovines with calmer temperaments gain more weight in comparison to those with more unquiet temperaments.

The shearing force values were similar across the studied genetic groups. According to Restle et al. (2003), zebu cattle are renowned for producing less tender meat than the animals with a part-Bos Taurus genotype. However, Maggioni et al. (2012) reported that zebu animals have meat with similar tenderness to that of crossbred Angus animals.

The correlation between the cortisol concentrations and the carcass characteristics are shown in Table 3.

According to Voisinet et al. (1997), agitated animals gain less weight, as seen in the correlation between average cortisol values and the ADG (-0.54; $\mathrm{p}<0.05)$. One can observe that in all collections, a negative correlation was found between the ADG and the cortisol level, confirming that animal weight gain is related to the susceptibility to stress in cattle. Thus, the animals considered more agitated also produce less tender meat. In this experiment, neither different shearing force values, nor significant correlation between shearing force and the serum cortisol level were observed among the genetic groups. 
Table 3. Pearson correlation coefficient of carcass characteristics and serum cortisol measurements.

\begin{tabular}{lccccccc}
\hline & ADG & SF & Collection 1 & Collection 2 & Collection 3 & Collection 4 & Collection 5 \\
\hline ADG & - & & & & & & \\
SF & $-0.34^{\text {ns }}$ & - & & & & & \\
Collection 1 & $-0.25^{\text {ns }}$ & $-0.10^{\text {ns }}$ & - & & & & \\
Collection 2 & $-0.39^{*}$ & $0.12^{\text {ns }}$ & $0.57^{*}$ & - & & & \\
Collection 3 & $-0.60^{*}$ & $0.36^{*}$ & $0.43^{*}$ & $0.50^{*}$ & - & & \\
Collection 4 & $-0.53^{*}$ & $0.17^{\text {ns }}$ & $0.80^{*}$ & $0.85^{*}$ & $0.76^{*}$ & - & - \\
Collection 5 & $-0.58^{*}$ & $0.14^{\text {ns }}$ & $0.77^{*}$ & $0.80^{*}$ & $0.76^{*}$ & $0.95^{*}$ & - \\
Ave. Collection & $-0.54^{*}$ & $0.15^{\text {ns }}$ & $0.71^{*}$ & $0.82^{*}$ & $0.74^{*}$ & $0.75^{*}$ & - \\
\hline
\end{tabular}

$* 5 \%$ significant correlation; ** 1\% significant correlation; ns - not significant. ADG: average daily gain. SF: shearing force.

\section{Conclusions}

Genetic make-up did not have an effect on serum cortisol concentrations, with the exception of the crossbred group Aberdeen Angus $\times$ Nelore, which demonstrated less susceptibility to stress when compared with the Nelore group.

The lowest average cortisol concentration, independent of the genetic group, was related to the greatest bovine average weight gain, and did not affect the qualitative aspects of the meat.

\section{References}

ABRAHÃO, J. J. S.; PRADO, I. N.; PEROTTO, D.; MOLETTA, J. L. Características de carcaças e da carne de tourinhos submetidos a dietas com diferentes níveis de substituição do milho por resíduo úmido da extração da fécula de mandioca. Revista Brasileira de Zootecnia, Viçosa, MG, v. 34, n. 5, p. 1640-1650, 2005.

ALVARENGA, E. A.; MOREIRA, G. H. F. A.; FACURY FILHO, E. J.; LEME, F. O. P.; COELHO, S. G.; MOLINA, L. R.; LIMA, J. A. M.; CARVALHO, A. U. Avaliação do perfil metabólico de vacas da raça Holandesa durante o período de transição. Pesquisa Veterinária Brasileira, Seropédica, v. 35, n. 3, p. 281-290, 2015.

BARBOSA, I. D. S.; FISCHER, V.; FARINATTI, L. H. E.; RESTLE, J.; ALVES FILHO, D. C. Relação entre genótipos e temperamento de novilhos Charolês $\times$ Nelore em confinamento. Revista Brasileira de Zootecnia, Viçosa, MG, v. 37, n. 10, p. 519-526, 2008.

BROWN, E. G.; CARSTENS, G. E.; FOX, J. T. Relationships between temperament and performance traits of growing calves. In: Beef Cattle Research in Texas Publication, section Physiology. 2004. 197 p.

FRASER, D.; RUSHEN, J. Aggressive behavior. In: PRICE, E.O. The veterinary clinics of North America: food animal practice. Philadelphia, Sanders, 1987. p. 285-305.

KABUGA, J. D.; APPIAH, P. A. Note on the ease of handling and flight distance of Bos indicus, Bos taurus and its crosses. Animal Science, Cambridge, v. 54, n. 2, p. 309-311, 1992.

HANKINS, O. G.; HOWE, P. E. Estimation of the composition of beef carcasses and cuts. Washington: United Sates Department of Agriculture, 1946. 19 p. (Technical Bulletin - USDA, 926).

KANITZ, E.; PUPPE, M.; TUCHSCHERER, M.; HEBERER, T.; VIERGUTZ, A.; TUCHSCHERER, A. A single exposure to social isolation in domestic piglets activates behavioural arousal, neuroendocrine stress hormones, and stress-related gene expression in the brain. Physiology \& Behavior, Elsevier, v. 98, n. 2, p. 176-185, 2009.

MAGGIONI, D.; PRADO, I. N.; ZAWADZKI, F.; VALERO, M. V.; ARAÚJO MARQUES, J. de; BRIDI, A. M.; SANTOS ABRAHÃO, J. J. dos. Grupos genéticos e graus de acabamento sobre qualidade da carne de bovinos. Semina: Ciências Agrárias, Londrina, v. 33, n. 1, p. 391-402, 2012.

MULLER, L. Normas para avaliação de carcaças e concurso de carcaça de novilhos. 2. ed. Santa Maria: Imprensa Universitária, 1987. $31 \mathrm{p}$.

OTTERSBACH, R. A.; SANTOS, R.; GERMANO, R. M. Variações de cortisol sérico em bovinos de corte (Bos taurus indicus) Nelore e (Bos taurus indicus $\times$ Bos taurus taurus) cruzamento industrial, durante o processo de abate. PUBVET, Londrina, v. 2, n. 42, p. 1-11, 2008. 
POCAY, P. L. B.; POCAY, V. G.; STARLING, J. M. C.; SILVA, R. G. Respostas fisiológicas de vacas holandesas predominantemente brancas e predominantemente negras sob radiação solar direta. Ars Veterinaria, Jaboticabal, v. 17, n. 2, p. 155-161, 2001.

RANDALL, M. The physiology of stress: cortisol and the hypothalamic- ituitary-Adrenal Axis. DUJS Online The Darmouth Undergraduate Journal of Science. Fall, Hanover NH, v. 13, n. 3, p. 22-24, 2011.

RESTLE, J.; VAZ, F. N.; BERNARDES, R. A. L. C.; PASCOAL, L. L.; MENEZES, L. F. G.; PACHECO, P. S. Características de carcaça e da carne de vacas de descarte de diferentes genótipos Charolês $\times$ Nelore, terminadas em confinamento. Ciência Rural, Santa Maria, v. 33, n. 2, p. 345-350, 2003.

STATISTICAL ANALYSIS SYSTEM INSTITUTE - SAS Institute. Stadical analysis user's guide: stat version 8.0. Cary: Institute, 2000.
SILVA, B.; POLETI, M. D.; MONCAU, C. T.; ROSA, A. F.; SILVA, S. L.; BALIEIRO, J. C. C. Características endócrinas, metabólicas e indicadoras da qualidade da carne em bovinos Nelore castrados e não castrados. Ciência Rural, Santa Maria, v. 44, n. 5, p. 904-910, 2014.

SILVEIRA, I. D. B.; FISCHER, V.; SOARES, G. J. D. Relação entre o genótipo e o temperamento de novilhos em pastejo e seu efeito na qualidade da carne. Revista Brasileira de Zootecnia, Viçosa, MG, v. 35, n. 2, p. 519526, 2006.

TIETZ, N. W. Clinical guide to laboratory tests. $3^{\text {th }}$ ed. Philadelphia: W.B. Saunders Company, 1995. 174 p.

VOISINET, B. D.; GRANDIN, T.; TATUM, S. F. Feedlot cattle with calm temperaments have higher average daily gains than cattle with excitable temperaments. Journal of Animal Science, Champaign, v. 75, n. 4, p. 892-896, 1997. 
